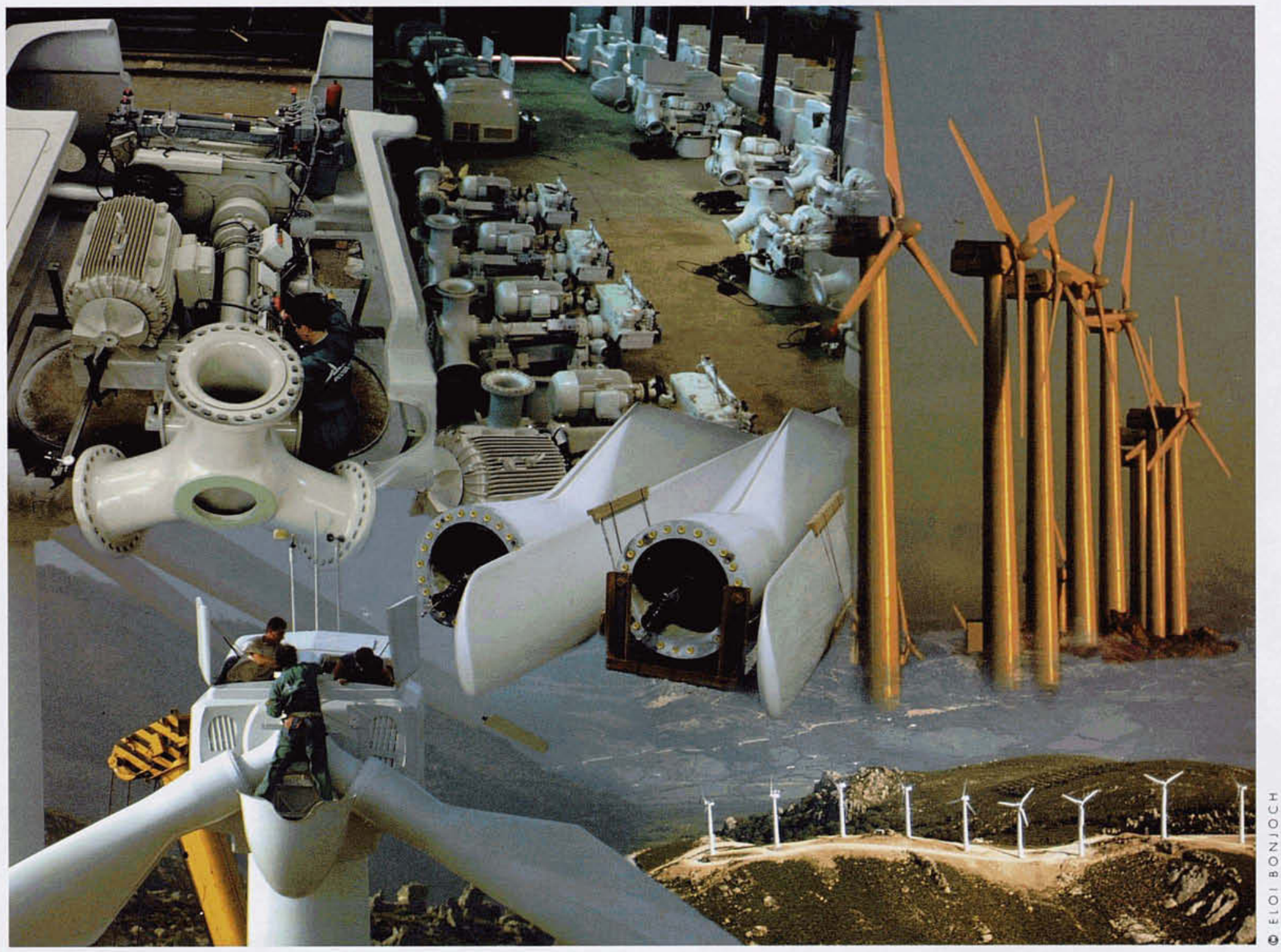

ECOTÉCNIA. WIND PARK AT TARIFA: ASSEMBLY, INSTALLATION, OPERATION 


\section{AUTOMATED MANUFACTURING}

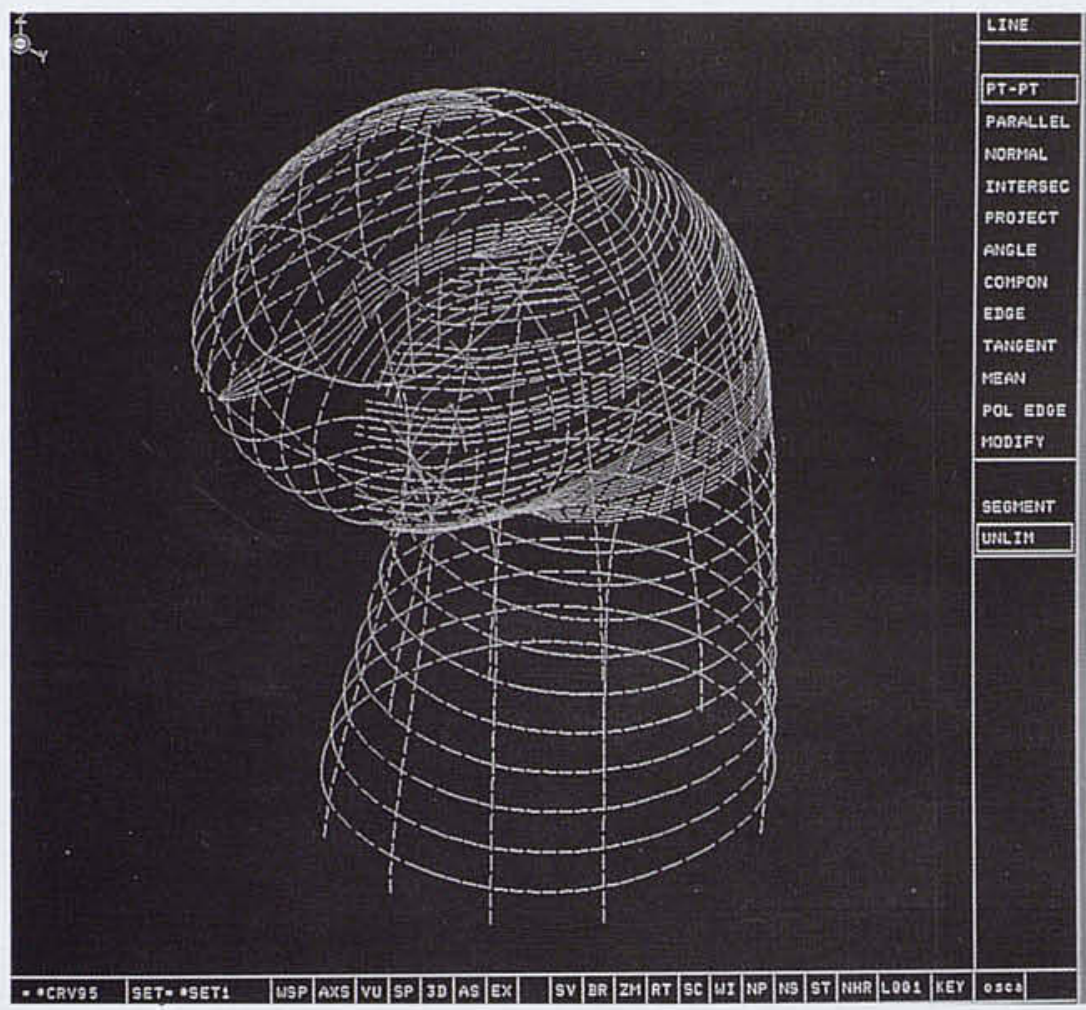

GEAR CHANGE SURFACE ADJUSTMENT

THE CIM CONCEPT IS A PHILOSOPHY RATHER THAN A SPECIFIC TYPE OF TECHNOLOGY. IT AIMS AT AN IDEAL FACTORY IN WHICH ALL THE PROCESSES, FROM DESIGN AND ENGINEERING TO MANUFACTURING, TRANSPORT AND CONTROL SYSTEMS, ARE COMPLETELY AUTOMATED. 


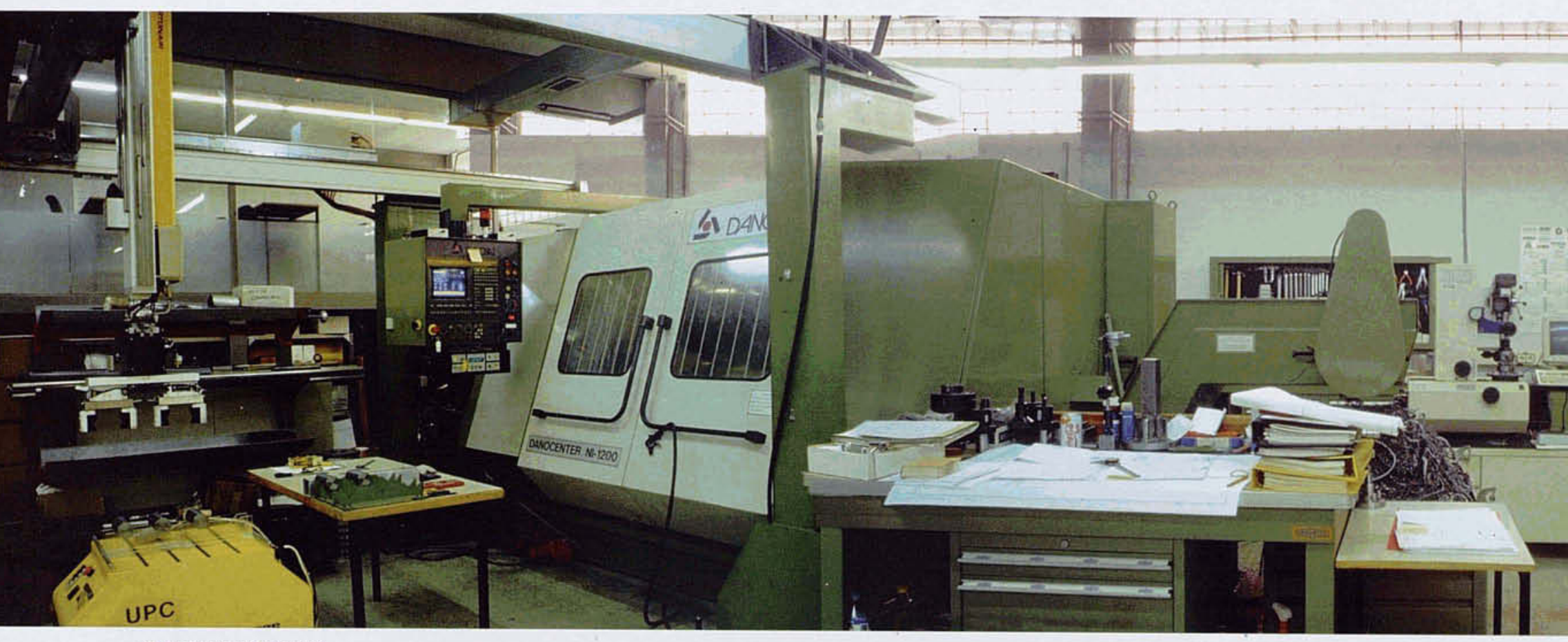

CIM CENTRE WORKSHOP

$\mathbf{T}$ he Centre for Computer Integrated Manufacturing is a flexible manufacturing laboratory set up by the Polytechnic University of Catalonia and the ICT (Catalan Institute of Technology). Set in the UPC's Southern Campus, it opened in June 1991 with the support of the Department of Industry of the Generalitat de Catalunya and the Spanish Ministry of Industry and Energy. Since then its work has been directed at providing information and training in the field of manufacturing technologies based on computer-assisted decision-taking and automated processes.

With this in mind, the CIM Centre has concentrated on research into advanced manufacturing processes and techniques in collaboration with the UPC departments; on services to local firms introducing and using techniques to improve productivity, and on training in new computer-assisted manufacturing technologies for students taking technical courses at the UPC and the ICT's College of Technology and for postgraduates and technical staff in industry. One of the main points in the collaboration between the CIM Centre and the industrial sector is the development of various projects centering on extending and demonstrating new computer-assisted manufacturing technologies, acting as a link between the University and local firms and facilitating Technology Transfer and the subsequent improvement in industrial productivity. One important aspect in this sense are the optimization studies in the design of products and processes and the industrial applications of inspection by artificial viewing (computer viewing), supervision and control programmes for automated production lines and automation diagnoses and studies. In the field of train- 


\section{DOSSIER}

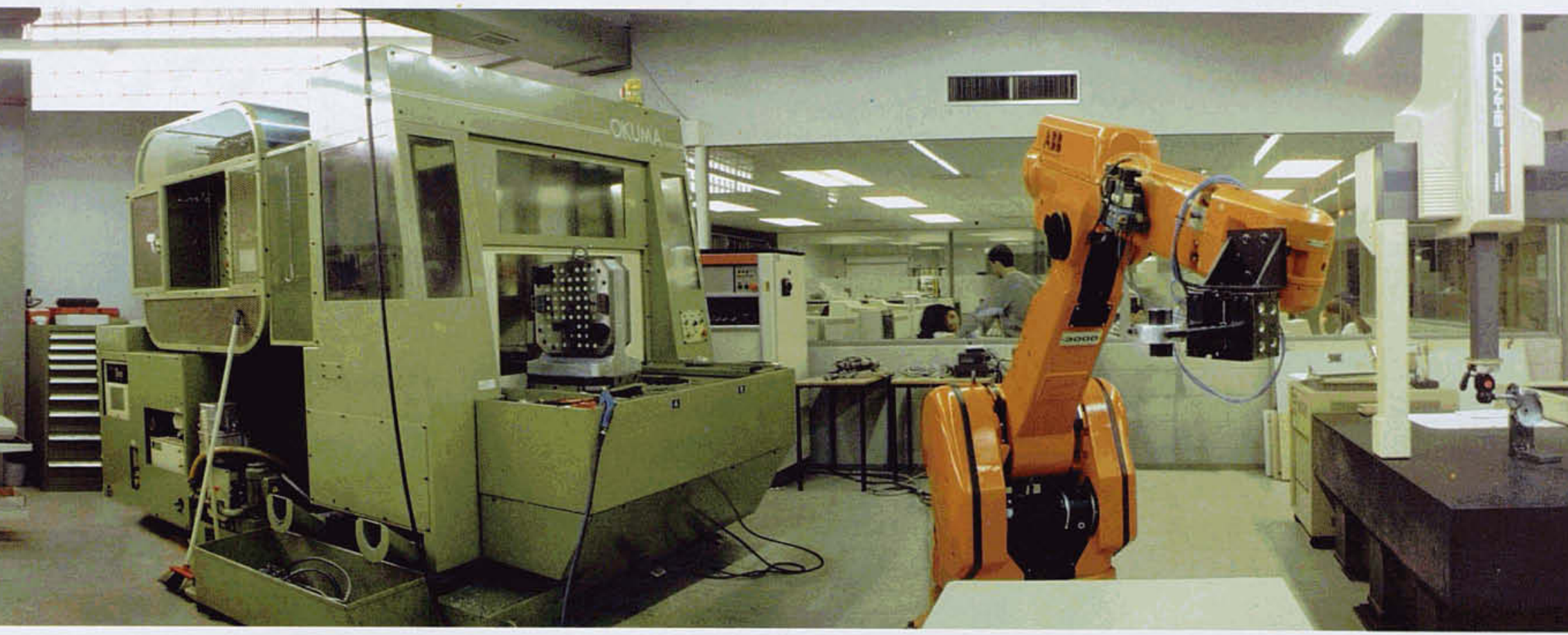

ing there are specialization courses such as the postgraduate course in Automated Production and Robotics.

The Centre's facilities include a manufacturing workshop made up of a series of flexible cells (lathing, milling, measuring, automatic storage, automated transport), all of them controlled and supervised by a central computer.

There is also a technical office with CAD-CAM-CAE equipment (computerassisted design, manufacturing and engineering) for designing both the product and the manufacturing process using concurrent engineering techniques. Simulated mechanization operations ensure that there will be no problems when it comes to manufacturing with real parts.

The links with official bodies such as the Generalitat's CIRIT IInterdepartmental Commission for Research and Technology) and with the Polytechnic University

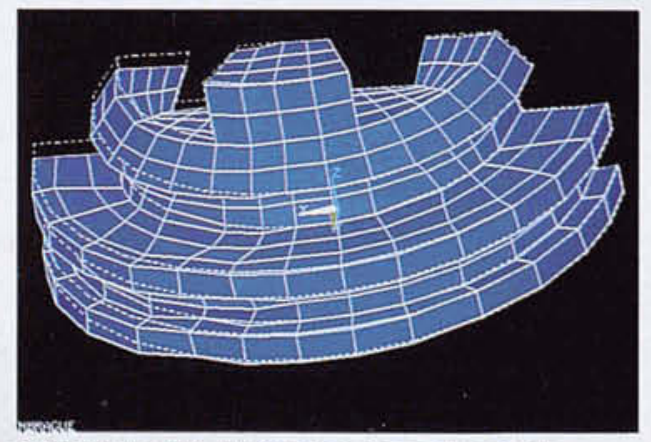

STUDY BY FINISHED ELEMENTS OF A CIUTCH DISK. FINAL GRAPHIC RESULTS of Catalonia through the Departments of Mechanical Engineering, of Systems, Automatic and Industrial Computer Engineering, and of Production Organisation allows the CIM Centre to work along five lines of research and technological development: concurrent engineering, computer viewing inspection, industrial communications, flexible cell management and integrated product management.

One of the results of this partnership has been the development and testing of a third-generation, radio-controlled AGV lautomatically guided, autonomous and adaptable vehicle) for moving materials between cells. This system needs no fixed installation to mark the route, since the path to be taken is introduced into the control computer and the vehicle is positioned by integration of the distance covered by the wheels. 